\title{
Evaluation of intercellular adhesion molecule-1 (ICAM-1), Tumor necrosis factor $\alpha$ (TNF- $\alpha$ ), Interleukins (IL-6, IL-8) and C-reactive protein (CRP) levels in neonatal calves with presumed septicemia
}

\author{
Yakup AKGÜL ${ }^{1} \quad$ Ömer AKGÜL ${ }^{2} \quad$ Süleyman KOZAT11 $\quad$ Cumali ÖZKAN1 \\ Abdullah KAYA ${ }^{1}$ Nedim YILMAZ ${ }^{3}$ \\ ${ }^{1}$ Van Yuzuncu Yil University, Faculty of Veterinary Medicine, Department of Internal Medicine, Van, Turkey \\ ${ }^{2}$ Van Yuzuncu Yil University, Faculty of Pharmacy, Department of Pharmaceutical Microbiolog, Van, Turkey \\ ${ }^{3}$ Van Metropolitan Municipality, Department of Animal Health, Van, Turkey
}

Received: 13.06 .2019

Accepted: 15.10 .2019

\begin{abstract}
In this study; intercellular molecule-1 (ICAM-1), Tumor necrosis factor $\alpha$ (TNF- $\alpha$ ), Interleukin-6 (IL-6), Interleukin-8 (IL-8) and C-reactive protein (CRP) levels were evaluated in neonatal calves with presumed septicemia. The material of this study consisted of a total of 30 calves. Study group consisted of 20 septicemic calves and 10 clinically healthy calves and with same breed and weight and their ages were between 1 and 10 days. The statistical analysis indicated that leukocyte (WBC), red blood cell (RBC), hematocrit (Hct) hemoglobin $(\mathrm{Hb})$ and mean corpuscular haemoglobin concentration (MCHC) values in neonatal calves with presumed septicemia were higher than those of the control group $(\mathrm{P}<0.05)$, whereas PLT values of neonatal calves with septicemia were lower than those of the control group $(\mathrm{P}<0.05)$. The levels of ICAM-1, TNF- $\alpha$, IL6, IL-8 and CRP values in septicemic calves were higher than those of the control group $(\mathrm{P}<0.05)$. As a result, it was concluded that analyzes of TNF- $\alpha$, IL-6, IL-8 and particularly ICAM- 1 concentrations may be considered in evaluating the severity and prognosis of patients with septicemia, as well as monitoring the efficacy of the treatment of the disease.
\end{abstract}

Keywords: Calf, Septicemia, Acute Phase Proteins, Cytokines, Intercellular adhesion molecule-1

\section{Septisemi Şüpheli Yenidoğan Buzağılarda Hücrelerarası Adhezyon Molekül-1 (ICAM-1), Tümör nekroz faktörü $\alpha$ (TNF- $\alpha$ ), İnterlökinler (IL-6, IL-8) ve C-reaktif protein (CRP) Seviyelerinin Değerlendirilmesi}

Bu çalışmada; septisemi şüpheli yenidoğan buzağılarda hücreler arası molekül-1 (ICAM-1), Tümör nekroz faktörü $\alpha$ (TNF- $\alpha$ ), İnterlökin-6 (IL-6), İnterlökin-8 (IL-8) ve C-reaktif protein (CRP) düzeyleri değerlendirildi. Bu çalışmanın materyalini aynı cins ve kiloya sahip ve yaşları 1-10 gün arasında değișen 20 septisemik buzağı ile 10 sağlıklı buzağı olmak üzere toplam 30 buzağı oluşturdu. İstatistiksel analizde, septisemili buzağıların lökosit (WBC), eritrosit (RBC), hematokrit (Hct) hemoglobin (Hb) ve ortalama korpüsküler hemoglobin konsantrasyonu (MCHC) değerleri kontrol grubunun aynı parametrelerine göre yüksek tespit edilirken (P $<0.05$ ), septisemili yenidoğan buzağıların PLT değerleri kontrol grubunun PLT değerlerine göre düșük (P $<0.05$ ) saptand. Septisemik buzağılarda ICAM-1, TNF- $\alpha$, IL-6, IL-8 ve CRP değerleri kontrol grubunun aynı değerlerine göre anlamlı düzeyde yüksek tespit edildi $(\mathrm{P}<0.05)$. Sonuç olarak, TNF- $\alpha$, IL-6, IL-8 ve özellikle ICAM-1 konsantrasyonlarının analizlerinin septisemili vakalarda hastalığın șiddetini ve prognozunu değerlendirmede yararlı parametreler olabileceği, bununla birlikte bu parametrelerin tedavi etkinliğinin takibinde göz önünde bulundurulması gereken parametreler olacağı kanısına varıldı.

Anahtar Kelimeler: Buzağı, Septisemi, Akut Faz Proteini, Sitokin, Hücre arası Adhezyon Molekül-1

\section{INTRODUCTION}

The neonatal period is one of the most critical stage in the development of farm animals, because morbidity and mortality rates of various diseases are highest during this period (Hammon et al. 2013). There are lots of factors that leads to yield loss and death in neonatal calves such as bacterial, viral, protozoal agents, environmental stressors and other diseases. These factors can result in serious economic losses (Bellows 2007). Among these etiological factors, septicemia in calves may also develop by passive transfer failure and exposure to invasive infectious agents 
(Basoglu et al. 2004; Kozat 2018). Septicemia is the entrance of microorganisms and toxins into blood flow and coexisting of general inflammation with host response (Karadal 2009). Infectious agents, such as bacteria, viruses, and fungi are the ones that begin with the stimulation of the immune system and lead to death as a result of multiple organ failure (Camcioğlu and Aytaç 2007). Although there have been several studies on septicemia in humans and animals at the present, the subject of pathophysiology of the disease has not yet been clarified at the desired level. In this context, sufficient information related with the function of a large number of endogenous mediators emerging within the septicemia process has not been achieved in ongoing studies. For this reason, performing advanced diagnostic methods and advanced techniques of treatment has not been able to provide the desired results. Intensive studies on the function of these mediators in the inflammatory process caused by septicemia are still on going. A number of mediators with different functions such as interleukins, polymorphonuclear cell complexes, interferons, macrophages, arachidonic acid metabolites, toxic oxygen metabolites occur after the initiation of the inflammation (Austgulen et al. 1997; Akgul et al. 2019). With the passage of microorganisms or toxins through the epithelial layer and into the subepithelial tissue, existing monocytes and macrophages recognize non-indigenous microorganisms entering the body and send the necessary signals to the adhesion molecules in the environment. This signaling event begins to release many cytokines such as TNF- $\alpha$, IL6, and IL-8 (Lofstedt et al. 1999; Basoglu et al. 2004; Ercan et al. 2014). Indeed, according to related studies; cytokines reach the highest levels in blood plasma and serum within 60-180 minutes during the development of bacteriemia and endotoxemia (Hack et al. 1989; Wakabayashi et al. 1991). High levels of cytokines are currently used in early detection of septicemia in newborns and adults (Waage et al. 1989; Bone et al. 1992; Lofstedt et al. 1999; Basoglu et al. 2004; Ercan et al. 2014). The release of cytokines varies depending on the type of pathogens (bacteria or viruses etc.) (Akgul et al 2019; Steel and Whitehead, 1994; Ercan et al. 2014). Increase in cytokines, especially IL-1, IL-6, and TNF- $\alpha 1$, in acute and chronic inflammatory events causes a release of acute phase proteins in the liver (Gökçe and Bozukluhan 2009; Ceciliani et al. 2012; Akgul et al. 2019). Adhesive molecules are molecules that act in cellular and cell-matrix interactions, and are released from endothelial cells, mononuclear cells and granulocytes. The appearance of these molecules on the surface of the cell takes about 2 4 hours (Barlow and Huntley 2000). They continue to exist and increase within 12-16 hours and maintain their presence for about 24-72 hours with continued stimulation of cytokines in the environment (Adams et al. 1990; Endo et al. 1995; Austgulen et al. 1997; Horadagoda et al. 2002). Adhesion molecules play an important role in the development of immunity and inflammatory response. Cells involved in the protection of the body exit the veins and go into the interstitial tissues and adhere to foreign microorganisms and destroy these microorganisms with a cytotoxic effect. This process is due to adhesion molecules (Mackay and Imhof 1993; Akgul et al. 2019). Numerous studies have been carried out on the importance of cytokines, acute phase proteins and adhesion molecules used in identifying septicemia in humans and animals (Hack et al. 1989; De Bont et al. 1993; Deveci et al. 2002; Lee et al. 2003; Petersen et al. 2004). Although the significance of these metabolic stimulants is not known in the course of the disease, information on the effectiveness of the diagnosis is still limited. Despite the fact that a large number of parameters can determine the activity of inflammation, this is not enough to control the effect on patients and the response to treatment for serious disease patterns. Okusawa et al. (1988) have proven that TNF- $\alpha$ has reached high levels. Similarly, in a study conducted by Pohlman et al. (1986) on rabbits, it was shown that TNF- $\alpha$ increases body heat and increases the adhesion of neutrophils. In a similar study by Rothstein and Schreiber (1988) on rats; it has been shown that systemic toxemia occurs when low doses of TNF- $\alpha$ are given to healthy rat, and a lethal shock occurs when TNF- $\alpha$ is given along with various bacteria. Dinarello (1991) indicated that adhesion molecules, as well as conventional methods of treatment, can be used in animals subjected to septic shock. Wakabayashi et al. (1991) reported that a significant increase in TNF- $\alpha$ levels was observed in bacteremia caused by E. coli and S. epidermidis, and necrosis of the liver, which developed simultaneously with leukopenia, thrombocytopenia, hypotension and infiltration of neutrophils. Basoglu et al. (2004) studied serum TNF- $\alpha$ levels in neonatal septicemic calves and determined TNF- $\alpha$ serum levels of healthy calves as $234 \pm 115 \mathrm{pg} / \mathrm{ml}$, and the levels in septicemic calves were $3.380 \pm 699 \mathrm{pg} / \mathrm{ml}$. In addition, the researchers suggested that the level of TNF- $\alpha$ should be above $464 \mathrm{pg} / \mathrm{ml}$ in septicemic calves in order to be positive. In another study performed by Barton and Collates (1999), TNF- $\alpha$ and IL-6 levels increased to $213 \pm 548 \mu \mathrm{g} / \mathrm{ml}$ and $3.018 \pm 8.022 \mu \mathrm{g} / \mathrm{ml}$, respectively. Nevertheless, Morris et al. $(1990 ; 1992)$ indicated that IL-6 levels increased in endotoxemia cases, and this increase was in parallel with the clinical data and laboratory parameters of the disease. Again, in a study conducted by MacKay et al. (1991) on endotoxemic horses; it was found that TNF- $\alpha$ levels increase during the course of the disease. Regarding acute phase proteins, Bayraktar et al. (2005) conducted a study on brucellosis in cattle, expressed the idea that the levels of CRP can be used as a supplement to the diagnosis. Likewise, Lee et al. (2003) stated that CRP reaches a high level in infections. Similarly, Bozukluhan et al. (2016) found in studies of cattle infected with brucella, that CRP levels were increased.

Kozat and Özkan (2018) reported an increase in ICAM-1 concentrations in calves infected with $M$. bovis. With respect to this topic, Cowley et al. (1994) found that serum ICAM-1 levels in patients with systemic inflammatory response syndrome (SIRS) were high. In the same study, it was found that ICAM-1 levels were higher in patients with multiple organ failure. Again in a similar study Kayal et al. (1998) reported that ICAM-1 levels in patients with septicemia increased in plasma in parallel with the development of multiple organ failure. Similarly, in a study by Sessler et al. (1995), it was found that the level of ICAM1 in serum was significantly higher in moribund patients with septic shock than in patients who survived. Similarly, Deveci et al. (2002) found that serum levels of ICAM-1 in septicemic children were an important predictor of diagnosis and prognosis of the disease. In the same way, Endo et al. (1995) expressed the view that the prognosis was poor in patients with multiple organ failure due to septicemia and high levels of ICAM-1, and adhesion molecule levels rapidly declined during healing as a result of treatment. In another study, Whalen et al. (2000) reported a significant increase in ICAM-1 levels in blood samples in children with multiple organ failure due to septicemia. Similarly, in a study conducted by Austgulen et al. (1997); the levels of ICAM-1 in neonatal septicemic children are high and can be used to diagnose the disease. As can be understood from the studies, it has been 
reported that levels of ICAM-1, TNF- $\alpha$, IL-6, IL-8 and CRP may contribute to the early diagnosis of septicemia and mortality (Adams et al. 1990; De Bont et al. 1993; Austgulen et al. 1997; Deveci et al. 2002). The main goal of this study is to determine the levels of ICAM-1, TNF- $\alpha$, IL-6, IL-8 and CRP which are useful in diagnosis and prediction of calf septicemia.

\section{MATERIALS and METHODS}

The study material was collected from a total of 30 calves, 10 healthy and 20 septic calves aged 1 to 10 days, delivered to the clinics of Veterinary Faculty of Yuzuncu Yil University. All calves were evaluated according to body temperatures, changes in general condition, respiratory and heart rates, appetite, environment, reflection to the current situation, the presence of diarrhea, changes in mental status and dehydration. In addition to these findings, calves that did not receive any medication included to the study. This research was approved (21/05/2015 and 27552122-295) by the Animal Research Ethics Committee of Van Yuzuncu Yil University in Van, Turkey.

\section{Analysis of hematological parameters}

To analyze hematological parameters according to the procedure, blood samples taken from the jugular vein in both healthy and septicemic calves was placed in anticoagulant tubes. Hematocrit (Hct), hemoglobin ( $\mathrm{Hb})$ concentration, leukocyte count (WBC), red blood cells (RBC), mean corpuscular haemoglobin concentration (MCHC) and platelet count (PLT) were analyzed at the same day (QBC Vetautoreader $®$-Idexx).

\section{Analysis of biochemical parameters}

To analyze the biochemical parameters, blood samples was taken from the jugular vein from both healthy and septicemic calves and placed in coagulant free tubes and centrifuged at room temperature at $3000 \mathrm{rpm} / 10 \mathrm{~min}$ for the removal of serum (Rotofix32 $₫$-Hettich). From the obtained sera, ICAM-1 (catalog number MBS017452), TNF$\alpha$ (catalog no: MBS2611057), IL-6 (Interleukin 6, catalog no: MBS887062), IL-8 (catalog no: MBS008105) and CRP (catalog no: MBS887532) concentrations were measured by ELISA device (DAS, Italy) according to the kit procedures.

\section{Analysis of microbiological agents}

For microbiological analysis, blood samples from the jugular vein of both healthy and calves with septicemia

Table 1. Hematological parameters in healthy and calves with septicemia

\begin{tabular}{|c|c|c|}
\hline Parameter & $\begin{array}{l}\text { Control group } \\
(n=10) \bar{x} \pm S D\end{array}$ & $\begin{array}{l}\text { Septicemia group } \\
(n=20) \bar{x} \pm S D\end{array}$ \\
\hline WBC $\left(10^{3} / \mathrm{mm}^{3}\right)$ & $13.79 \pm 3.41^{\mathrm{a}}$ & $27.67 \pm 12.10^{b}$ \\
\hline $\operatorname{RBC}\left(10^{6} / \mathrm{mm}^{3}\right)$ & $9.95 \pm 1.38^{a}$ & $10.25 \pm 2.43^{\mathbf{b}}$ \\
\hline Het (\%) & $37.88 \pm 3.86^{\mathrm{a}}$ & $41.49 \pm 11.105^{b}$ \\
\hline $\mathrm{Hb}(\mathrm{g} / \mathrm{dl})$ & $11.96 \pm 1.27 \mathrm{a}$ & $13.63 \pm 3.10^{b}$ \\
\hline MCHC (g/dl) & $31.53 \pm 1.38^{\mathrm{a}}$ & $33.39 \pm 5.14^{\mathbf{b}}$ \\
\hline PLT $\left(10^{3} / \mathrm{mm}^{3}\right)$ & $302 \pm 16^{a}$ & $250 \pm 18 b$ \\
\hline
\end{tabular}

$\bar{X} \pm S D$ : mean \pm standart deviation.

a, b: Different lower cases in the same column represent statistically significant differences $(P<0.05)$. were taken on condition that they were not in contact with air and 5-10 $\mathrm{ml}$ of blood in each tubes were placed in $30 \mathrm{ml}$ bottles with aerobic and anaerobic cultures (Bact/Alert ${ }^{\circledR}$ ). Blood culture bottles containing blood samples were sent to the Microbiology Laboratory of the Medical Faculty of Yuzuncu Yil University for bacteriological identification and placed in device for Blood Culture (Bact/Alert® 3D Left Combination Module). For bacteriological isolation, aerobic (sheep bloody agar, McConkey agar and Eosin Methylen Blue Agar-Salubris ${ }^{\circledR}$ ) and anaerobic (Shadler liquid medium and Anaerob Agar-Salubris $®$ ) nutrient media were used. The performed factor analysis showed that the presence of septicemia is final. The isolated bacteria were identified by automated microbiological systems BD Phoenix (Becton Dickinson, USA) at the level of the genus and species and the results of the antibiogram analysis were presented.

Descriptive statistics for the studied features are presented as mean and standard deviation. The Independent two-sample t-test was used to compare groups for these characteristics. For all statistical analyses, IBM SPSS ver. 20 software was used.

\section{RESULTS}

\section{Clinical findings}

According to clinical examination of healthy animals, there were no health problems, and the body condition was in normal level depending on age and sex. Body temperatures of healthy calves were determined as $37.86 \pm 1.32 \stackrel{\circ}{\circ} \mathrm{C}$. Body temperatures of septicemic calves was found as $38.40 \pm 2.10^{\circ} \mathrm{C}$. However, it was also found that dehydration, weakening of the suction reflex and diarrhea were most common, while the vast majority of the calves in the severe group were lying down, completely lost interest to the environment, had decreased suckling reflex, changes in mental status and strong dehydration.

\section{Results of hematological parameters}

In this study, hematological parameters of septicemic calves are presented in Table 1.

In statistical analysis, WBC, RBC, Hct, $\mathrm{Hb}$ and MCHC values of neonatal calves with septicemia were higher than those of the control group $(\mathrm{P}<0.05)$, whereas PLT values of neonatal calves with septicemia were lower than those of the control group $(\mathrm{P}<0.05)$. 
Table 2. Serum ICAM-1, TNF- $\alpha$, IL-6, IL-8 and CRP levels in healthy and calves with septicemia

\begin{tabular}{lll}
\hline Parameter & $\begin{array}{l}\text { Control group } \\
\mathbf{( n = 1 0 )} \\
\overline{\mathbf{x}} \pm \text { SD }\end{array}$ & $\begin{array}{l}\text { Septicemia } \\
\text { (n=20) } \\
\overline{\mathbf{x}} \pm \text { SD }\end{array}$ \\
\hline ICAM-1 (ng/L) & $414.77 \pm 266.10^{\mathbf{a}}$ & $1205.225 \pm 450.10^{\mathbf{b}}$ \\
TNF- $\alpha$ (ng/L) & $306.53 \pm 87.21^{\mathbf{a}}$ & $469.10 \pm 15.10^{\mathbf{b}}$ \\
IL-6 (ng/L) & $538.77 \pm 259.98^{\mathbf{a}}$ & $1101.81 \pm 313.85^{\mathbf{b}}$ \\
IL-8 (ng/L) & $66.40 \pm 46.37^{\mathbf{a}}$ & $217.27 \pm 93.39 \mathbf{b}$ \\
CRP (ng/L) & $13.64 \pm 3.68^{\mathbf{a}}$ & $24.19 \pm 7.51^{\mathbf{b}}$ \\
\hline
\end{tabular}

$\mathrm{X} \pm \mathrm{SD}$ : mean \pm standart deviation.

a, b: Different lower cases in the same column represent statistically significant differences $(\mathrm{P}<0.05)$.

\section{Results of biochemical parameters}

Biochemical results are presented in Table 2. ICAM-1, TNF$\alpha$, IL-6, IL-8 and CRP values in septicemic calves were higher than those of the control group $(\mathrm{P}<0.05)$.

\section{Results of microbiological parameters}

According to the results of blood culture tests E. coli, Enterococcus faecalis, Enterococcus faecium, Staphylococcus aureus, Streptococcus pneumonia, Campylobacter fetus, Salmonella spp. and Bacillus spp. were isolated and identified.

\section{DISCUSSION}

Despite numerous studies in the treatment of neonatal calf diseases were undertaken, a high mortality rate for these diseases remains an important problem (Çitil and Gökçe, 2013, Kozat and Tuncay, 2018). In this regard, high mortality and serious economic losses occur in our country, especially after calf birth (Çakıroğlu et al. 2010; Çitil and Gökçe, 2013; Kozat, 2018). In this context, sepsis is known as a fatal disease, because of the rapid onset of septicemia and the septic shock that causes multiple organ failure. For this reason, this disease has become an important subject that many researchers are currently considering. In this context, studies on early diagnosis and treatment of this disease have continued to reduce high mortality in neonates (Michaels and Banks 1988; Gerros et al. 1995; Doellner et al. 1998; Doellner et al. 2001).

The number of red blood cells can be reduced in the process of the disease, and sepsis becomes more noticeable in a prolonged inflammatory process. In fact, according to various studies, important changes in the blood profile may occur in neonatal septicemic calves (Gerros et al. 1995; Lofstedt et al. 1999). However, it has also been reported that there cannot be a rapid change in erythrocyte levels during the first 72 hours of infection (Weinberg et al. 1988; Barton and Collates 1999; Deveci et al. 2002; Basoglu et al. 2004). Similarly, it was noted that in this study there was significant change in the level of red blood cells, since both groups of patients were at the initial stage of infection (Table 1). On the other hand, WBC, $\mathrm{RBC}, \mathrm{Hct}, \mathrm{Hb}$ and MCHC values of neonatal calves with septicemia were higher than those of the control group $(\mathrm{P}<0.05)$, whereas PLT values of neonatal calves with septicemia were lower than those of the control group $(\mathrm{P}<0.05)$. It was found that changes and increase in total leukocyte counts are consistent with previous studies (Lofstedt et al. 1999; Deveci et al. 2002; Basoglu et al. 2004; Ercan et al. 2014).
In parallel with changes in the blood profile of septic animals, clinical data soon begin to appear in sick animals (Adams et al. 1990; Gerros et al. 1995; Barton and Collates 1999; Horadagoda et al. 2002). In these animals, symptoms such as alterations in body temperature, tachycardia, depression, loss of appetite, loss of suckling reflex and changes in mental status are considered to be major clinical symptoms (Michaels and Banks 1988, Gerros et al. 1995, Lofstedt et al. 1999, Basoglu et al. 2004). Similarly, findings obtained in this study supports the datas of the above researchers.

A number of studies on the process of septicemia in humans (Dinarello 1991; Deveci et al. 2002;) and animals (Bozukluhan et al. 2016) have been carried out, which have shown that several microorganisms activate a large number of adhesion molecules, cytokines and acute phase proteins after they enter the body (Adams et al. 1990; Ay et al. 1998; Bayraktar et al. 2005; Kozat and Ozkan 2018). In this study, the level of the stated mediators (ICAM-1, TNF- $\alpha$, IL-6, IL-8, and CRP) in blood plasma or serum after infection with microorganisms in neonatal calves infected with sepsis was observed to determine to what results this would lead. In this context, numerous studies have been conducted in human medicine, where the ICAM- 1 adhesion molecule plays an important role in many stages of the inflammatory process (Austgulen et al. 1997; Ay et al. 1998; Deveci et al. 2004; Terekeci et al. 2008).

There are several studies showing that ICAM-1 may be an important diagnostic marker for septic diseases in human medicine (Cowley et al. 1994; Endo et al. 1995; Deveci et al. 2004; Terekeci et al. 2008). Sessler et al. (1995) reported that ICAM-1 levels markedly increased in patients with septic shock. Cowley et al. (1994) found that in patients with systemic inflammatory response syndrome, ICAM-1 serum levels were significantly increased. The same researchers stated that ICAM-1 levels were present in high concentrations in patients with multiple organ failure. In a similar study, Kayal et al. (1998) showed that ICAM-1 levels increase in plasma in patients with sepsis in parallel with the syndrome of multiple organ failure. Similarly, in a study conducted by Endo et al. (1995); it was suggested that the prognosis is worsened in patients with multiple organ failure due to septicemia and high levels of ICAM-1, and adhesion molecule levels rapidly declined during healing as a result of treatment. Whalen et al. (2000) reported a significant increase in ICAM-1 levels in blood samples in children with multiple organ failure due to septicemia. Similarly, in a study conducted by Austgulen et al. (1997); the levels of ICAM-1 in neonatal septicemic children are high and can 
be used for diagnosing the disease. However, there are also studies suggest that ICAM-1 cannot be used as a single marker in patients with septicemia (Cowley et al. 1994; Deveci et al. 2002). Although ICAM-1 is the subject of several studies in the field of human medicine, there are not enough studies related with this subject in veterinary field (Kozat and Ozkan 2018). In this study, it was found that significant changes in the level of adhesion molecules occurred within the first 24-48 hours from the onset of infection in calves with septicemia and that these changes may be used to diagnose the disease. However, it was concluded that early treatment of septicemia and related scientific research in this direction could prevent the disease.

It is understood that various studies have been conducted in different parts of the world regarding the levels of cytokines in the development of septicemic diseases in animals (Horadagoda et al. 2002; Basoglu et al. 2004). In these studies, several cytokines and acute phase proteins were shown to be important for the diagnosis of the disease (Adams et al. 1990; Waage et al. 1989; Barton and Collates 1999; Akgul et al. 2019). It is emphasized that these mediators are especially important for TNF- $\alpha$, IL-6 and IL-8, and that these mediator levels increase in septic human diseases (Martin et al. 2001; Mehr et al. 2001). Despite detailed studies of cytokine levels are present for the treatment of septicemic diseases in human medicine (Martin et al. 2001; Mehr et al. 2001), research on this topic in animal medicine is still at an insufficient level. On the topic of animal diseases, Murtaugh et al. (1996) found that, cytokines such as IL-6, IL-8 and TNF- $\alpha$ increase in animal diseases. Similarly, in another study conducted by Dandona et al. (1994) following the administration of endototoxins to experimental animals, they found that TNF- $\alpha$ and IL-6 levels increased within the first 2-3 hours and continued to grow to 4 hours, but after 24 hours plasma levels were too low to measure. Natanson et al. (1989) studied endotoxemia in dogs and found a rise in TNF- $\alpha$ concentrations. In a similar way, Barton and Collates (1999) studied the level of cytokine changes in horses with detected endotoxemia and reported an increase in TNF- $\alpha$ and IL- 6 levels. Besides, Nakajima et al. (1997) studied coliform bovine mastitis and found that plasma levels of TNF- $\alpha$ and IL- 6 were significantly higher than those in the control group. Similarly, in an experimental study conducted by Horadagoda et al. (2002) on calves, it was reported that the serum TNF- $\alpha$ level reached the highest level in the first hour of $P$. haemolytica infection, but then quickly fell to an undetectable level within 4 hours. Caswell et al. (1998) found that, in cattle with pneumonia, IL-8 levels in bacterial and viral pneumonia were measured and IL-8 levels found in patients with bacterial origin were significantly higher than levels in patients with viral origin. Adams et al. (1990) found a marked increase of TNF- $\alpha$ level in cases of endotoxemia developing in calves. Similarly, in a study by Fischer et al. (2016) for calf diarrhea an increase of IL-6 was demonstrated. Basoglu et al. (2004) reported that, serum TNF- $\alpha$ levels in newborn septicemic calves were higher than healthy calves. Besides, Ercan et al. (2014) conducted a study of blood parameters and biomarkers in newborn calves; it was reported that they measured TNF- $\alpha$ and IL-8 concentrations as $0.667 \pm 0 \mathrm{ng} / \mathrm{ml}$ and $199.1 \pm 8.4$ $\mathrm{pg} / \mathrm{ml}$, respectively.

It seems that most detailed and extensive studies have been made at the levels of mediators that result from the activity of microorganisms with septicemic diseases developing in newborn calves. Thus, at the time of planning this study, there was not any detailed study found related with the function and levels of TNF- $\alpha$, IL-6, IL-8, ICAM-1 and CRP during inflammations, particularly severe disease period and concurrent septic shock. It is thought that performing a study related with this subject will fulfill the literature need. Thus, in this research, changes of inflammatory mediators in the disease process of calves following birth were studied. In this study, the levels of ICAM-1, TNF, IL-6, IL-8 and CRP increased in the first 24-48 hours in a group of calves with septicemia. For this reason, the values determined in the control group were not considered as initial values, and comparison with groups of sick animals was not performed. Indeed, the levels of cytokines in healthy animals were lower than those determined in this study compared to previous studies of cytokine levels in calves (Adams et al. 1989; Basoglu et al. 2004; Ercan et al. 2014).

According to the results of our study, it was found that in the group of calves with septicemia, the level of ICAM-1 was $1205.225 \pm 450.10 \mathrm{ng} / \mathrm{l}$, the level of TNF- $\alpha$ was $469.10 \pm 15.10 \mathrm{~b} \mathrm{ng} / \mathrm{l}$, the level of IL- 6 was $1101.81 \pm 313.85$ ng/l, IL-8 was $217.27 \pm 93.39 \mathrm{ng} / \mathrm{l}$, and CRP levels were $24.19 \pm 7.51 \mathrm{ng} / \mathrm{l}$. It was found that calves with septicemia have a higher level of these parameters compared to the results of previous studies in healthy calves. In fact, Basoglu et al. (2004) found $234 \pm 115 \mathrm{ng} / \mathrm{ml}$ of TNF- $\alpha$ levels in healthy calves. Nakajima et al. (1997) reported $20 \mathrm{ng} / \mathrm{ml}$ for IL-6 levels in healthy calves. Ercan et al. (2014) and Molina (2005) reported that in healthy calves, the levels of IL-8 were $199.187 \pm 8.433$ and between $150-200 \mathrm{pg} / \mathrm{ml}$ in healthy calves.

When assessing our results from the moment of infection of the calves with septicemia, it was shown that the levels of ICAM-1, TNF- $\alpha$, IL-6, IL- 8 and CPR remained high. Results obtained in our study is similar with the results of previous studies (Waage et al. 1989; De Bont et al. 1993; Doellner et al. 1998; Hirao et al. 2000; Deveci et al. 2002; Horadagoda et al. 2002; Lee et al. 2003; Basoglu et al. 2004). However, when comparing ICAM-1 levels of patients with septicemia with our study; increased ICAM-1 levels may be used for diagnosing septicemia in calves. Similarly, Austgulen et al. (1997) found that ICAM-1 levels were $258.9 \mu \mathrm{g} / \mathrm{L}$ in neonatal infants and $394.2 \mu \mathrm{g} / \mathrm{L}$ in infected infants. Nevertheless, Deveci et al. (2002) found that ICAM-1 levels in healthy children were $277.9 \pm 52.0$ $\mathrm{ng} / \mathrm{ml}$, and ICAM levels in septic children were 855.0 \pm 126.9 . In this study, it was found that ICAM-1 levels in septicemic calves were $1205.225 \pm 450.10 \mathrm{ng} / \mathrm{L}$. However, no comparison was made, because ICAM-1 levels were higher than the required values in the blood serum measurements obtained from healthy calves selected as a control group. Increase in ICAM-1 levels of septicemic calves when compared to control group supports the datas of the researchers.

\section{CONCLUSION}

As a conclusion, the results of all parameters associated with this study showed that in both human and veterinary medicine, could be used as important criteria for diagnosing septicemia. We believe that concentrations of ICAM-1, TNF- $\alpha$, IL-6, IL-8 and CRP can be used in the early stages of diagnosing septicemic diseases in the calves, especially when determining prognosis and progression of disease. 


\section{ACKNOWLEDGEMENTS}

This study was financed by Van Yuzuncu Yil University, Scientific Research Projects Coordination Unit, Project number 2015-VF-B302.

\section{REFERENCES}

Adams JL, Semrad SD, Czuprynski CJ (1990). Administration of bacterial lipopolysaccharide elicits circulating tumor necrosis factor-alpha in neonatal calves. J Clin Microbiol, 28(5), 998-1001.

Akgul 0, Kozat S, Ozkan C, Kaya A, Akgul Y (2019). Evaluation of acute phase protein levels and some cytokine levels in pneumonic calves. Med. Weter, 75(3), 152-157.

Austgulen R, Arntzen KJ, Haereid PE, Aag S, Dollner H (1997). Infections in neonates delivered at term are associated with increased serum levels of ICAM-1 and E-selectin. Acta Paediatrica, 86(3), 274-280.

Ay M, Gürbilek M, Vatansev H (1998). Acute phase proteins. J Gen Intern Med, 8(3): 125-32.

Barlow JZ, Huntley GW (2000). Developmentally regulated expression of Thy-1 in structures of the mouse sensory-motor system. J Comp Neurol, 421(2), 215-233.

Barton MH, Collates C (1999). Tumor necrosis factor and interleukin-6 activity and endotoxin concentration in peritoneal fluid and blood of horses with acute abdominal disease. J Vet Intern Med, 13(5), 457-464.

Basoglu A, Sen I, Sevinc M, Simsek A (2004). Serum concentrations of tumor necrosis factor- $\alpha$ in neonatal calves with presumed septicemia. J Vet Intern Med, 18(2), 238-241.

Bayraktar M, Bayraktar N, Bayındır Y, Durmaz R (2005). Brusellozlu hastalarda serum C-reaktif protein, demir ve ferritin düzeylerinin tan ve izlemdeki değeri. Antibiyotik ve Kemoterapi Derneği, 19(2), 61-3.

Bellows RA (2007). Factors affecting calf survival. Range Beef Cow Symposium, p.152

Bone RC, Balk RA, Cerra FB, Dellinger RP, Fein AM, Knaus WA, Sibbald WJ (1992). Definitions for sepsis and organ failure and guidelines for the use of innovative therapies in sepsis. Chest, 101(6), 1644-1655.

Bozukluhan K, Merhan 0, Büyük F, Çelebi Ö, Gökçe G (2016). Detection of the levels of some acute phase proteins in cattle with brucellosis. Vet J Ankara Univ, 63, 13-16.

Camcioğlu Y, Aytaç E (2007). Immunopathogenesis of sepsis. J Turk Soc Intens Care, 5, 1, 81-85.

Caswell JL, Middleton DM, Sorden SD, Gordon JR (1998). Expression of the neutrophil chemoattractant interleukin-8 in the lesions of bovine pneumonic pasteurellosis. Vet Pathol, 35(2), 124-131.

Ceciliani F, Ceron JJ, Eckersall PD, Sauerwein H (2012). Acute phase proteins in ruminants, J Proteomics, 75, 14, 4207-4231.

Cowley HC, Heney D, Gearing AJ, Hemingway I, Webster NR (1994). Increased circulating adhesion molecule concentrations in patients with the systemic inflammatory response syndrome: a prospective cohort study. Crit Care Med, 22 (4), 651-657.

Çakıroğlu D, Meral Y, Pekmezci D, Onuk EE, Gökalp G (2010). Yeni doğan buzağılarda çeșitli hematolojik ve biyokimyasal parametreler ile kolostral immun globulinler arasındaki ilişkinin belirlenmesi, F Ü Sağ Bil Vet Derg, 24, 1, 43-46.

Çitil M, Gökçe E (2013). Neonatal septisemi, Turkiye Klinikleri J Vet Sci, 4 , 1, 62-70.

Dandona P, Nix D, Wilson MF, Aljada A, Love J, Assicot M, Bohuon C (1994). Procalcitonin increase after endotoxin injection in normal subjects. J Clin Endocrinol Metab, 79(6), 1605-1608.

De Bont E, Martens A, Van Raan J, Samson G, Fetter W, Okken A, De Leij L (1993). Tumor necrosis factor- $\alpha$, interleukin- $1 \beta$, and interleukin- 6 plasma levels in neonatal sepsis. Pediatric Res, 33(4), 380-383.

Deveci U, Ayaz S, Ayaz A, Elevli M (2002). Sepsisli çocuklarda serum interselüler adezyon molekülü-1 düzeyleri. Çocuk Sağlı̆̆ı ve Hastalıkları Dergisi, 45, 162-168.

Dinarello CA (1991). The proinflammatory cytokines interleukin-l and tumor necrosis factor and treatment of the septic shock syndrome. J Infect Dis, 163(6), 1177-1184.

Doellner H, Arntzen KJ, Haereid PE, Aag S, Austgulen R (1998). Interleukin-6 concentrations in neonates evaluated for sepsis. J Pediatr, 132(2), 295-299.

Endo S, Inada K, Kasai T, Takakuwa T, Yamada Y, Koike S, Yoshida M (1995). Levels of soluble adhesion molecules and cytokines in patients with septic multiple organ failure. J Inflamm 46 (4), 212-219.

Ercan N, Tuzcu N, Başbuğ O, Gök K, Işıdan H, Oğrak YZ (2014). The evaluation of important biomarkers in healthy cattle. Kafkas Univ Vet Fak Derg, 20(5), 749-755.
Fischer S, Bauerfeind R, Czerny CP, Neumann S (2016). Serum interleukin-6 as a prognostic marker in neonatal calf diarrhea. J Dairy Sci, 99(8), 6563-71.

Gerros TC, Semrad SD and Proctor RA (1995). Alterations in clinical, hematological and metabolic variables in bovine neonatal endotoxemia. Can J Vet Res, 59(1), 34.

Gökçe Hİ, Bozukluhan K (2009). Important acute phase proteins in farm animals and their use in Veterinary Medicine. J Fac Vet Med Univ Dicle, $1,1,1-14$.

Hack CE, De Groot ER, Felt-Bersma RJ, Nuijens JH, Van Schijndel RS, Eerenberg-Belmer AJ, Aarden LA (1989). Increased plasma levels of interleukin-6 in sepsis. Blood, 74(5), 1704-1710.

Hammon HM, Steinhoff-Wagner J, Flor J, Schönhusen U, Metges CC (2013). Lactation Biology Symposium: role of colostrum and colostrum components on glucose metabolism in neonatal calves. Anim Sci, 91(2), 685-695.

Hirao Y, Kanda T, Aso Y, Mitsuhashi M, Kobayashi I (2000). Interleukin8-an early marker for bacterial infection. Laboratory Medicine, 31(1), 39-44.

Horadagoda NU, Hodgson JC, Moon GM, Wijewardana TG, Eckersall PD (2002). Development of a clinical syndrome resembling haemorrhagic septicaemia in the buffalo following intravenous inoculation of Pasteurella multocida serotype B: 2 endotoxin and the role of tumor necrosis factor- $\alpha$. Res Vet Sci, 72(3), 194-200.

Karadal AE (2009). SIRS ve sepsis hastalarında deksmedetomidin ve propofolün immün sistem üzerine etkileri, Çukurova Üniversitesi Tıp Fakültesi Anestezi ve Reaniamsyon Anabilim Dalı, Uzmanlık Tezi, Adana.

Kayal S, Jaïs JP, Aguini N, Chaudiere J, Labrousse J (1998). Elevated circulating E-selectin, intercellular adhesion molecule 1, and von Willebrand factor in patients with acute infection. Am J Respir Crit Care Med, 157(3), 776-784.

Kozat S, Tuncay I (2018). Prevalance of Rotavirus, Coronavirus, Cryptosprodium spp., Escherichia coli K 99, and Giardia lamblia pathogens in neonatal calves with diarrheic in Siirt Region. Van Vet J, 29 (1), 17-22.

Kozat S (2018). Hypothermia in newborn calves. Ist Vet Sci, 2(1), 30-37.

Kozat S, Ozkan C (2018). Intercellular adhesion molecule-1 (ICAM-1) and C-Reactive Protein (CRP) levels in calves naturally infected with Mycoplasma bovis. Int J Vet and Animal Res, 1(2), 34-37.

Lee WC, Hsiao HC, Wu YL, Lin JH, Lee YP, Fung HP, Chu RM (2003). Serum C-reactive protein in dairy herds. Can J Vet Res, 67(2), 102

Lofstedt J, Dohoo IR, Duizer G (1999). Model to predict septicemia in diarrheic calves. J Vet Intern Med, 13(2), 81-88.

MacKay RJ, Merritt AM, Zertuche JM, Whittington M, Skelley LA (1991) Tumor necrosis factor activity in the circulation of horses given endotoxin. Am J Vet Res, 52(4), 533-538.

Mackay CR, Imhof BA (1993). Cell adhesion in the immune system. Immunol Today, 14(3), 99-102.

Martin H, Olander B, Norman M (2001). Reactive hyperemia and interleukin 6, interleukin 8 , and tumor necrosis factor- $\alpha$ in the diagnosis of early-onset neonatal sepsis. Pediatrics, 108(4), 61-6.

Mehr SS, Doyle LW, Rice GE, Vervaart P, Henschke P (2001). Interleukin-6 and interleukin-8 in newborn bacterial infection. Am J Perinatol, 18(06), 313-324.

Michaels FH, Banks KL (1988). Contribution of various host factors to resistance to experimentally induced bacterial endotoxemia in calves. Am J Vet Res, 49(4), 557-562.

Molina EC (2005). Serum interferon-gamma and interleukins- 6 and- 8 during infection with Fasciola gigantica in cattle and buffaloes. Am J Vet Res, 6(2), 135-139.

Morris DD, Crowe N, Moore IN (1990). Correlation of clinical and laboratory data with serum tumor necrosis factor activity in horses with experimentally induced endotoxemia. Am J Vet Res, 51(12): 19351940.

Morris DD, Moore JN, Crowe N, Moldawer LL (1992). Effect of experimentally induced endotoxemia on serum interleukin-6 activity in horses. Am J Vet Res, 53(5), 753-756.

Murtaugh MP, Baarsch MJ, Zhou Y, Scamurra RW, Lin G (1996). Inflammatory cytokines in animal health and disease. Vet Immunol Immunopathol, 54(1-4), 45-55.

Nakajima Y, Mikami 0, Yoshioka M, Motoi Y, Ito T, Ishikawa Y, Yasukawa K (1997). Elevated levels of tumor necrosis factor- $\alpha$,(TNF$\alpha$ ) and interleukin-6 (IL-6) activities in the sera and milk of cows with naturally occurring coliform mastitis. Res Vet Sci, 62(3), 297-298.

Natanson C, Eichenholz PW, Danner RL, Eichacker PQ, Hoffman WD, Kuo GC, Parrillo JE (1989). Endotoxin and tumor necrosis factor challenges in dogs simulate the cardiovascular profile of human septic shock. J Exp Med, 169(3), 823-832. 
Okusawa S, Gelfand JA, Ikejima T, Connolly RJ, Dinarello C (1988). Interleukin 1 induces a shock-like state in rabbits. Synergism with tumor necrosis factor and the effect of cyclooxygenase inhibition. J Clin Invest, 81(4), 1162.

Petersen HH, Nielsen JP, Heegaard PMH (2004). Application of acute phase protein measurements in veterinary clinical chemistry. Vet Res, 35(2), 163-187.

Pohlman TH, Stanness KA, Beatty PG, Ochs HD, Harlan JM (1986). An endothelial cell surface factor (s) induced in vitro by lipopolysaccharide, interleukin 1 , and tumor necrosis factor-alpha increases neutrophil adherence by a CDw18-dependent mechanism. J Immunol, 136(12), 4548-4553.

Rothstein JL, Schreiber H (1988). Synergy between tumor necrosis factor and bacterial products causes hemorrhagic necrosis and lethal shock in normal mice. Proc Natl Acad Sci U S A, 85(2), 607-11.

Sessler CN, Windsor AC, Schwartz M, Watson L, Fisher BJ, Sugerman HJ, Fowler AA (1995). Circulating ICAM-1 is increased in septic shock. Am J Respir Crit Care Med, 151(5), 1420-1427.

Steel DM, Whitehead AS (1994). The major acute phase reactants: Creactive protein, serum amyloid $\mathrm{P}$ component and serum amyloid $\mathrm{A}$ protein, Immunol Today, 15, 2, 81-88.
Terekeci MH, Şahan B, Top C (2008). Hücre adezyon molekülleri. Nobel Medicus, 4(1), 4-10.

Waage S, Brandtzaeg P, Halstensen A, Kierulf P, Espevik T (1989). The complex pattern of cytokines in serum from patients with meningococcal septic shock. Association between interleukin 6, interleukin 1, and fatal outcome. J Exper Med, 169(1), 333-338.

Wakabayashi G, Gelfand JA, Jung WK, Connolly RJ, Burke JF, Dinarello CA (1991). Staphylococcus epidermidis induces complement activation, tumor necrosis factor and interleukin-1, a shock-like state and tissue injury in rabbits without endotoxemia. Comparison to Escherichia coli. J Clin Invest, 87(6), 1925.

Weinberg JR, Wright DJM, Guz A (1988). Interleukin-1 and tumour necrosis factor cause hypotension in the conscious rabbit. Clin Sci, 75(3), 251-255.

Whalen MJ, Doughty LA, Carlos TM, Wisniewski SR, Kochanek PM Carcillo JA (2000). Intercellular adhesion molecule-1 and vascular cell adhesion molecule- 1 are increased in the plasma of children with sepsis-induced multiple organ failure. Crit Care Med, 28(7), 26002607. 